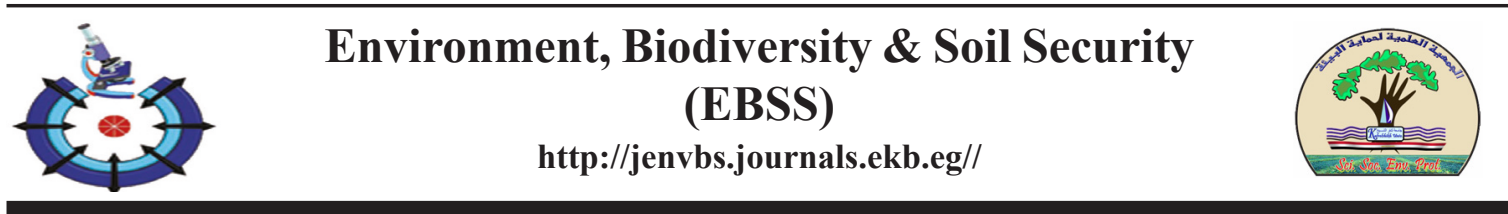

\title{
The Effect of Silicon on Minimizing the Implications of Water Stress on Tomato Plants
}

\author{
Mohamed F. Abd El- Aziz \\ Soils, Water and Environment Research Institute (SWERI), Agric. Research Centre
}

(ARC), Giza

\begin{abstract}
W ATER scarcity is a global issue especially in arid regions and rationalizing the use of fresh irrigation water has become necessary to satisfy water needs. The current study investigates using $\mathrm{Si}$ to alleviate the implications of water stress on tomato plants grown on a light textured soil. A split-plot experiment was conducted under the field conditions for two successive seasons (2017 and 2018) on tomato under two deficit irrigation levels i.e. 70 and $85 \% \mathrm{ET}_{\mathrm{c}}$ as well as $100 \% \mathrm{ETc}$ for comparison. Plants were subjected to two levels of silica foliar spray $(0$ and $0.4 \mathrm{mM}$ ). At physiological maturity growth stage, chemical characteristics of tomato fruits as well as total fruit yield were determined. Deficit irrigation decreased contents of chlorophyll A and B in leaves; while increased proline content in plant roots. This consequently decreased tomato fruit yield; while, raised its contents of total dissolved solids and vitamin C. On the other hand, spraying plants with Si raised significantly chlorophyll A and B in leaves and alleviated plant stress by increasing proline content in roots. This increased significantly fruit yield. Irrigation with $85 \% \mathrm{Et}_{\mathrm{c}}$ with $\mathrm{Si}$ spray recorded a rather similar fruit yield to those irrigated with $100 \% \mathrm{Et}_{\mathrm{c}}$. Moreover, Si treatments increased significantly water use efficiency by the crop. Thus, Si spray can take part in saving considered amounts of water that can be used for irrigation of further tomato areas.
\end{abstract}

Keywords: Tomato; Water use efficiency; Deficit irrigation; Si spray; Proline

\section{Introduction}

Tomato (Lycopersicon lycopersicum L.) is an important fruit vegetable that belongs to the Solanaceae family (Tóth and Takácsné Hájos 2019). It is the second important crop after potato (Ayyar, 2019) which is characterized by high economic (De la Torre-González et al., 2018) and nutritional importance worldwide (Borghesi et al., 2018). Its importance is growing year by year (Tóth and Takácsné Hájos, 2019). However, its fruit yield and quality is negatively affected by water stress (Zhang et al., 2017). Water scarcity has grown up to become a global problem (Dolatyar and Gray, 2000) especially in arid regions (Rafaat, 2020; Mbava et al. 2020; Abdelhafez et al. 2020; Bassouny and Abbas 2020 and Zekri \& Al-Maamari, 2020). In Egypt many farmers suffer from shortage of irrigation water (AbdAllah et al. 2019; Assar et al. 2020 and Farid et al., 2020) particularly at the end of the irrigation channels (Farid et al., 2014). Thus, the Egyptian government use untraditional water resources to satisfy irrigation needs (Abbas and Bassouny, 2019; Farid et al., 2019 and Bassouny et al., 2020). However, such waters are not enough to satisfy all irrigation requirements (Ali et al., 2016). Therefore, rationalizing the use of fresh irrigation water has become necessary to satisfy water needs (Farid et al., 2014). This might take place through following partial root zone drying (PRD) and/or regulating deficit irrigation (Tahi et al., 2008) to increase the efficiency of water use (Tahi et al., 2007). Introducing untraditional materials such as using biochar (Bassouny \& Abbas, 2019 and Elshony et al., 2019), K (Liu et al., 2019) or Si (Domokos-Szabolcsy et al., 2017; Amer and El- Emary 2018; Saad \& Abo-Koura, 2018 and Zarger et al. 2019) may alleviate water stress. Silicon which is one of the most abundant

"Corresponding author : E-mail:engfouad24@gmail.com

Received 27/04/2020; Accepted 27/06/2020

DOI: $10.21608 /$ jenvbs.2020.28732.1092

C2020 National Information and Documentation Center (NIDOC) 
elements in the earth's crust (Jurkowska and Świerczewska-Gładysz, 2020) may have an important role in increasing plant tolerance to water stress (Teixeira et al. 2020). Thus, providing plant with Si has been adopted as an important treatment for alleviating the adverse implications of drought (Sithanantham et al., 2020).

Deficit irrigation affects vegetative and reproductive growth stages of tomato and reduces the rate of cluster formation and fully formed fruits (Gladden et al., 2012). Supplying tomato plants with $\mathrm{Si}$ can conserve water by up to $23 \%$ (Cao et al., 2017), hence, its use can be of high potential economic return (Marodin et al., 2014). In spite of the high content of Si in soil (Kaushik and Saini, 2019), its available forms of silicic acid or mono silicic acid $\left[\mathrm{Si}(\mathrm{OH})_{4}\right.$ or $\left.\mathrm{H}_{4} \mathrm{SiO}_{4}\right]$ (Zarger et al. 2019), seem to be limited under water shortage conditions (Grašič et al., 2017). No active Si uptake system was detected in tomato plants (Sun et al. 2019). Thus, foliar application of Si can positively alleviate deficit irrigation (Dawa et al., 2019).

The current study investigates the potentiality of using Si to alleviate the implications of deficit irrigation on tomato plants grown on a light textured soil.

\section{Materials and Methods}

A field experiment was carried out for two successive summer seasons (2017 and 2018) at El.Adelia farm, Belbeis (El Sharqia Governorate) to investigate the effects of spraying plants with $\mathrm{Si}$ on increasing the productivity of tomato plants subjected to deficit irrigation and at the same time, increasing the water use efficiency. Before conducting the field trial, a surface soil sample $(0-30 \mathrm{~cm})$ was collected from the study area for physical and chemical analyses according to Klute (1986) and Page et al. (1982). The results are presented in Table 1.

\section{The experimental design and field protocol}

A split-plot field experiment was conducted to assess Si effect on tomato under deficit irrigations. The main plots were assigned to irrigation treatments of $100 \% \%$ ETc (equivalent to 7074 and $7286 \mathrm{~m}^{3} \mathrm{ha}^{-1}$ during 2017 and 2018, respectively), $85 \%$ ETc and $70 \%$ ETc. The subplots were assigned to foliar spray with Si treatments of 0 and $0.4 \mathrm{~m} M$ in the form of potassium silicate. The experimental plot comprised one ridge 1.2 $\mathrm{m}$ width $\times 5 \mathrm{~m}$ length and all treatments were performed in triplicates. On the $1^{\text {st }}$ of April of the two successive years 2017 and 2018, tomato (Lycoperson essulentum, var Beto86) transplants were cultivated on one side of ridges at a distance of $0.5 \mathrm{~m}$ within the row (each plot contained 10 plants). NPK fertilizers were applied to all plots at the recommended rates $\left(\mathrm{kg} \mathrm{ha}^{-1}\right)$ as follows: 160 $\mathrm{kg} \mathrm{N}$ (as $\mathrm{NH}_{4} \mathrm{NO}_{3}, 330 \mathrm{~g} \mathrm{~N} \mathrm{~kg}^{-1}$ ), $66.67 \mathrm{~kg} \mathrm{P}$ in the form of calcium superphosphate $\left(67 \mathrm{~g} \mathrm{P} \mathrm{kg}^{-1}\right)$ and $62 \mathrm{~kg} \mathrm{~K}$ in the form of potassium sulphate. Phosphate was added during soil preparation while $\mathrm{N}$ and $\mathrm{K}$ were applied through fertigation through the drip irrigation system. After 70 days of transplanting, 5 whole plants were collected randomly from each plot, where chlorophyll $\mathrm{A}$ and $\mathrm{B}$ were extracted from their leaves by ethanol, then determined photometrically, while proline content was extracted from their dried root materials (70 C for 48hr) and quantified according to Bates et al. (1973).

At physiological maturity growth stage, tomato fruit yield was determined and their chemical characteristics were determined according to the standard methods described by AOAC (2000) i.e. total soluble solids (TSS) by refractometer and ascorbic acid by titration against $\mathrm{NaOH}$ in presence of 2,6-di-chlorophenolindophenol as an indicator.

Irrigation water characteristics and irrigation scheduling

The main characteristics of the Nile water used for irrigation in this study were assessed according to the standard methods outlined in Richards (1954) and are presented in Table 2.

Irrigation scheduling was based on the monthly averages of the meteorological data of the Egyptian Meteorological Authrity (EMA) from April to July in the two seasons, i.e. 2017 and 2018 (Table 3). Data were introduced into CropWat 8 Software for calculation of crop evapotranspiration (ETc) and reference evaporation (ETo) according to Benman Montith equation and FAO (Allen et al. 1998) as follows:

$$
\mathbf{E T}_{\mathrm{c}}=\mathrm{ET}_{\mathrm{o}} \times \mathrm{K}_{\mathrm{c}}
$$

Equation 1

Where: $\mathrm{ET}_{\mathrm{c}}$ in $\mathrm{mm}, \mathrm{ET}_{\mathrm{o}}$ in $\mathrm{mm}$, and $\mathrm{K}_{\mathrm{c}}$ is the crop coefficient

The irrigation water requirement was calculated according to the following equation: $\mathbf{I W R}=(\mathbf{E T c}) / \mathbf{I E}$

Equation 2

Where: IWR is the irrigation water requirement and IE is the irrigation efficiency (estimated by $85 \%$ for drip irrigation system according to Suramani and Prabakaran (2015). 
TABLE 1. Physical and chemical properties of the soil under study prior to the fist and second growing seasons.

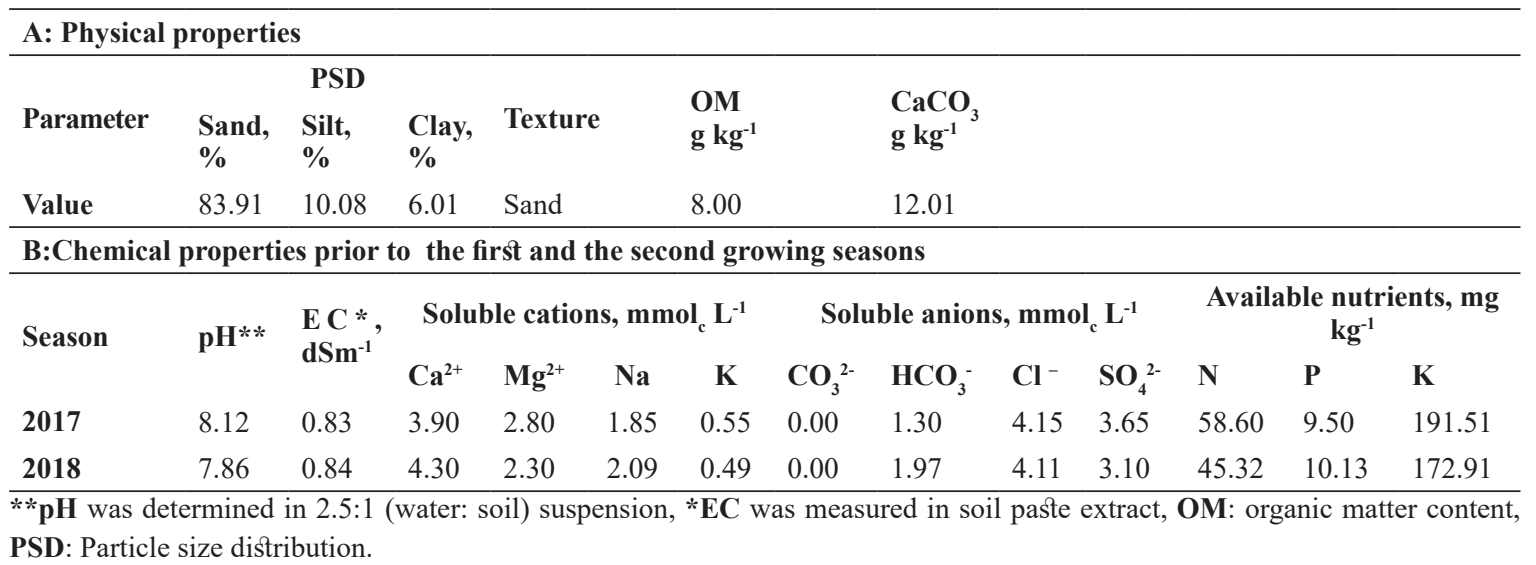

TABLE 2. Main characteristics of the Nile water used in irrigation of the tomato plant .

\begin{tabular}{lllllllllll}
\hline Character & $\mathbf{p H}$ & $\mathbf{E C}, \mathbf{d S}$ & \multicolumn{3}{c}{ Soluble cations, $\mathbf{m m o l} \mathbf{L}^{-1}$} & \multicolumn{3}{c}{ Soluble anions, $\mathbf{m m o l}_{\mathbf{c}} \mathbf{L}^{-1}$} \\
& & $\mathbf{m}^{-\mathbf{1}}$ & $\mathbf{C a}^{2+}$ & $\mathbf{M g}^{2+}$ & $\mathbf{N a}^{+}$ & $\mathbf{K}^{+}$ & $\mathbf{C O}_{3}^{2-}$ & $\mathbf{H C O}_{3}^{-}$ & $\mathbf{C l}^{-}$ & $\mathbf{S O}_{4}{ }^{2-}$ \\
\hline $\mathbf{2 0 1 7}$ & 7.35 & 0.37 & 1.8 & 1.0 & 0.9 & 0.2 & 0.0 & 2.7 & 1.0 & 0.2 \\
$\mathbf{2 0 1 8}$ & 7.26 & 0.45 & 2.4 & 1.3 & 0.6 & 0.4 & 0.0 & 2.9 & 1.3 & 0.5 \\
\hline
\end{tabular}

TABLE 3. Calculated values of the crop evapo-transpiration (ET) and the corresponding ones of the irrigation water requirement (IWR) for the tomato growth period.

\begin{tabular}{lcccc}
\hline \multirow{2}{*}{ Month } & \multicolumn{2}{c}{$\mathbf{E T}_{\mathbf{c}}\left(\mathbf{m}^{3} \mathbf{h a}^{-1}\right)$} & \multicolumn{2}{c}{ IWR $\left(\mathbf{m}^{3} \mathbf{h a}^{-1}\right)$} \\
\hline April & $\mathbf{2 0 1 7}$ & $\mathbf{2 0 1 8}$ & $\mathbf{2 0 1 7}$ & $\mathbf{2 0 1 8}$ \\
May & 1226.40 & 1281.60 & 1442.83 & 1507.76 \\
June & 1512.86 & 1619.52 & 1779.76 & 1905.24 \\
July & 1569.60 & 1605.60 & 1846.60 & 1888.95 \\
Total & 1703.76 & 1686.40 & 2004.43 & 1984.00 \\
\hline
\end{tabular}

Values of $\mathrm{ET}_{\mathrm{c}}$ and IWR in $\mathrm{mm}$ were then transformed into the corresponding values in $\mathrm{m}^{3}$ $\mathrm{ha}^{-1}$ 'through multiplication by 10

\section{Statistical analysis}

The obtained data were statistically analyzed using SPSS 18 statistical software through the analysis of variance according to Gomez and Gomez (1984). Duncan multiple range test method at the $5 \%$ level of probability was used to compare among the means of treatments. Water use efficiency (WUE)/water productivity (WP) values were also calculated according to Booker and Trees (2020) and Durand et al. (2020) as the crop yield in kilograms divided by the amount of water consumed in the production of this yield in cubic meters "crop per drop".

Water use efficiency (WUE)= (Tomato fruit yield $(\mathrm{kg})) /($ irrigation water Equation 3 requirements $\left.\left(m^{\wedge} 3\right)\right)$

\section{Results and Discussion}

Tomato fruit yield grown under water deficit conditions as affected by Si application

Figure 1 and Table 4 reveal that tomato fruit yield decreased significantly with decreasing the amount of irrigation water from $100 \% \mathrm{ET}_{\mathrm{c}}$ to $70 \%$ $\mathrm{ET}_{\mathrm{c}}$. In this concern, the fruit yield attained due to irrigation with $100 \% \mathrm{ET}$ was 1.2 fold higher than that attained due to $70 \% \mathrm{ET}_{\mathrm{c}}$ (during the 
two successive years of study). Water constitutes $92 \%-95 \%$ of the mature tomato fruit (Hanssens et al., 2015). This water contributes effectively to increasing the fruit volume probably as a result of increasing sap influxes through phloem and xylem fluxes (Guichard et al., 2005). The stress conditions affect negatively cell division with undesirable impacts on fruit water and osmotic potentials (Ripoll et al., 2016). On the other hand, results obtained herein indicate that $\mathrm{Si}$ application alleviated, to some extent, the consequences of deficit irrigation on the grown plants. This element improved growth of tomato plants during the two years of study. This may have activated "osmotic adjustment and improving aquaporin activity" (Chen et al., 2018). It seems that the fruit yield obtained by irrigation with $85 \% \mathrm{ET}_{\mathrm{c}}$ +spray with $\mathrm{Si}$ recorded slight variations from those irrigated with $100 \% \mathrm{ET}_{\mathrm{c}}$ (with or without $\mathrm{Si}$ ) during both seasons of study. This may indicate that $\mathrm{Si}$ can ameliorate the negative impacts of deficit irrigation on tomato plants.

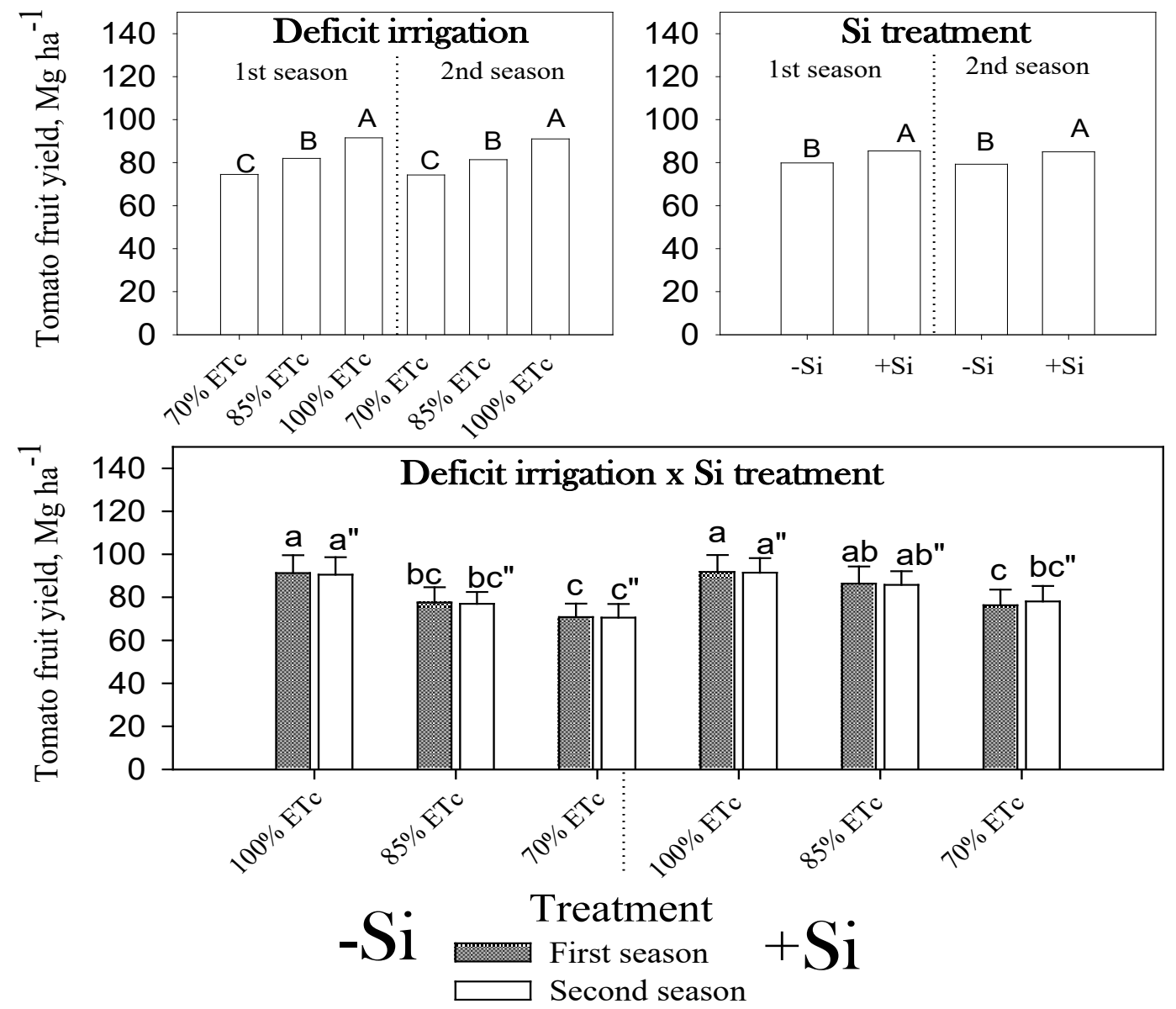

Fig. 1. Fruit yield $\left(\mathrm{Mg} \mathrm{ha}^{-1}\right)$ as affected by deficit irrigation and Si foliar application. There were no significant variations among values of the same letter

TABLE 4. Fruit yield (Mg ha-1) as affected by deficit irrigation and Si foliar application

\begin{tabular}{|c|c|c|c|c|c|c|c|c|}
\hline & \multicolumn{4}{|c|}{ First season } & \multicolumn{4}{|c|}{ Second season } \\
\hline $\begin{array}{l}\text { Si } \\
\text { spray }\end{array}$ & $100 \% \mathrm{ET}_{\mathrm{c}}$ & $\mathrm{ET}_{\mathrm{c}} 85 \%$ & $\mathrm{ET}_{\mathrm{c}} \mathbf{7 0 \%}$ & Mean & $100 \% \mathrm{ET}_{\mathrm{c}}$ & $\mathrm{ET}_{\mathrm{c}} 85 \%$ & $\mathrm{ET}_{\mathrm{c}} \mathbf{7 0 \%}$ & Mean \\
\hline$-\mathbf{S i}$ & $91.3 \pm 8.3^{\mathrm{a}}$ & $77.6 \pm 7.1^{\mathrm{bc}}$ & $70.8 \pm 6.3^{\mathrm{c}}$ & $79.9^{\mathrm{B}}$ & $90.6 \pm 8.1^{\mathrm{a}}$ & $77.0 \pm 5.5^{\mathrm{bc}}$ & $70.6 \pm 6.4^{c}$ & $79.3^{\mathrm{B}}$ \\
\hline$+\mathbf{S i}$ & $91.8 \pm 7.9^{\mathrm{a}}$ & $86.4 \pm 8.0^{\mathrm{ab}}$ & $76.3 \pm 7.3^{\mathrm{c}}$ & $85.5^{\mathrm{A}}$ & $91.5 \pm 6.8^{\mathrm{a}}$ & $85.6 \pm 6.4^{\mathrm{ab}}$ & $78.1 \pm 7.2^{\mathrm{bc}}$ & $85.1^{\mathrm{A}}$ \\
\hline Mean & $91.6^{\mathrm{A}}$ & $81.9^{\mathrm{B}}$ & $74.5^{\mathrm{C}}$ & - & $90.1^{\mathrm{A}}$ & $81.4^{\mathrm{B}}$ & $74.3^{\mathrm{C}}$ & - \\
\hline
\end{tabular}

There were no significant variations among values of the same letter, Si treatments:-Si: no Si spray; +Si: spray with 0.4 m M K-silicate $+S i$ : spray with $0.4 \mathrm{~m} \mathrm{MK}$-silicate. 


\section{Tomato fruit quality parameters}

Fruit quality parameters affect fruit storage, transport and processing (de Vos et al., 2018). The two quality parameters, considered in the current research, are total dissolved solids (TDS) and vitamin C. Data in Table 5 reveals that the quality parameters increased significantly in tomato plants grown under water stress conditions. These results agree with those of Zhang et al. (2017) who found that soluble solids content and vitamin $\mathrm{C}$ increased under water stress conditions. These components may improve plant water balance (Nahar and Ullah, 2018). On the other hand, Si application seemed to have negative implications on those two parameters. These results are similar to those reported by Jarosz (2014) who stated that vitamin $\mathrm{C}$ decreased in plants sprayed with $\mathrm{Si}$. This might result because of the dilution effect of these components in fruits sprayed with $\mathrm{Si}$. The increase in TDS within tomato fruits owing to spraying with silicon can alleviate salt-induced osmotic stress (Zhu and Gong, 2014).

\section{Proline in plant roots}

Proline content in plant roots increased significantly due to deficit irrigation (Fig. 2 and Table 6). Such increase was more pronounced with irrigation deficit. Such increases reflects the tendency of tomato plants to adjust their cells osmotically (Nahar and Ullah 2018). Regarding the effect of spraying plants with $\mathrm{Si}$ on improving the growth performance under deficit irrigations, Si caused a slight increase in proline content in plant. Such increase was particularly significant in the second growing season. This would increase tolerance to osmotic stress (Ali et al., 2018). Such results do not support the hypothesis that the osmo-regulations in plants grown under stress conditions and treated with Si were mainly related to proline content. There may be other mechanisms causing increased plant tolerance against drought stress. The highest proline content was attained in plants irrigated with $70 \% \mathrm{ET}_{\mathrm{c}}$ and sprayed with Si during the two seasons of study.

\section{Chlorophyll content}

Table 7 reveals that chlorophyll content (A, B and total) decreased significantly in tomato leaves subjected to deficit irrigation. According to the chlorophyll contents in leaves, the irrigation treatments can be arranged in the following descending order: $100 \% \mathrm{ET}_{\mathrm{c}}>85 \% \mathrm{ET}_{\mathrm{c}}>70 \%$ $\mathrm{ET}_{\mathrm{c}}$. These results agree with the findings of Tahi et al (2018) who reported that chlorophyll content in tomato leaves decreased significantly in plants subjected to deficit irrigation. They attributed this to increase in activities of oxidative stress enzymes in tomato plants (superoxide dismutase, soluble peroxidase and polyphenol oxidase). Spraying plants with silicon raised significantly the chlorophyll content (A, B and total) in tomato leaves. Results of research elsewhere showed increases in chlorophyll content, and photochemical efficiency of PSII under stress conditions (Al-aghabary et al., 2005 and Cao et al., 2015). Other results showed that Si alleviates the oxidative damage in plants (Shi et al., 2014).

TABLE 5. Total dissolved solids (TDS) and vitamin C in tomato fruits as affected by deficit irrigation and Si foliar application

\begin{tabular}{|c|c|c|c|c|c|c|c|c|}
\hline \multirow{2}{*}{$\begin{array}{l}\mathrm{Si} \\
\text { spray }\end{array}$} & \multicolumn{4}{|c|}{ First season } & \multicolumn{4}{|c|}{ Second season } \\
\hline & $100 \% \mathrm{ET}_{\mathrm{c}}$ & $\mathrm{ET}_{\mathrm{c}} \mathbf{8 5 \%}$ & $\mathrm{ET}_{\mathrm{c}} \mathbf{7 0 \%}$ & Mean & $100 \% \mathrm{ET}_{\mathrm{c}}$ & $E_{\mathrm{c}} 85 \%$ & $\mathrm{ET}_{\mathrm{c}} \mathbf{7 0 \%}$ & Mean \\
\hline \multicolumn{9}{|c|}{ Total dissolved solids (TDS) } \\
\hline$-\mathbf{S i}$ & $5.10 \pm 0.46^{c}$ & $5.50 \pm 0.51^{\mathrm{bc}}$ & $6.30 \pm 0.55^{\mathrm{a}}$ & $5.63^{\mathrm{A}}$ & $4.91 \pm 0.42^{\mathrm{c}}$ & $5.80 \pm 0.51^{\mathrm{ab}}$ & $6.40 \pm 0.51^{\mathrm{a}}$ & $5.70^{\mathrm{A}}$ \\
\hline$+\mathrm{Si}$ & $5.20 \mathrm{~b} \pm 0.43^{\mathrm{c}}$ & $5.30 \pm 0.36^{\mathrm{bc}}$ & $5.90 \pm 0.53^{\mathrm{ab}}$ & $5.47^{\mathrm{A}}$ & $4.85 \pm 0.36^{\mathrm{c}}$ & $5.10 \pm 0.46^{\mathrm{bc}}$ & $6.10 \pm 0.50^{\mathrm{a}}$ & $5.35^{\mathrm{B}}$ \\
\hline Mean & $5.15^{\mathrm{B}}$ & $5.4^{\mathrm{B}}$ & $6.1^{\mathrm{A}}$ & - & $4.88^{\mathrm{C}}$ & $5.45^{\mathrm{B}}$ & $6.25^{\mathrm{A}}$ & - \\
\hline \multicolumn{9}{|c|}{ Vitamin C } \\
\hline$-\mathbf{S i}$ & $26.78 \pm 1.92^{\mathrm{a}}$ & $28.60 \pm 2.35^{\mathrm{a}}$ & $31.50 \pm 2.74^{\mathrm{a}}$ & $28.96^{\mathrm{A}}$ & $26.50 \pm 2.13^{\mathrm{a}}$ & $30.20 \pm 2.52^{\mathrm{a}}$ & $32.20 \pm 3.04^{\mathrm{a}}$ & $29.63^{\mathrm{A}}$ \\
\hline$+\mathrm{Si}$ & $26.62 \pm 2.11^{\mathrm{a}}$ & $27.50 \pm 2.39^{\mathrm{a}}$ & $30.10 \pm 2.70^{\mathrm{a}}$ & $28.07^{\mathrm{A}}$ & $25.90 \pm 1.84^{\mathrm{a}}$ & $27.89 \pm 2.54^{\mathrm{a}}$ & $31.50 \pm 2.84^{\mathrm{a}}$ & $28.43^{\mathrm{A}}$ \\
\hline Mean & $26.70^{\mathrm{C}}$ & $28.05^{\text {B }}$ & $30.80^{\mathrm{A}}$ & - & $26.20^{\mathrm{C}}$ & $29.05^{\text {в }}$ & $31.85^{\mathrm{A}}$ & - \\
\hline
\end{tabular}

There were no significant variations among values of the same letter,Si treatments:-Si: no Si spray;+Si: spray with $0.4 \mathrm{~m}$ M K-silicate 

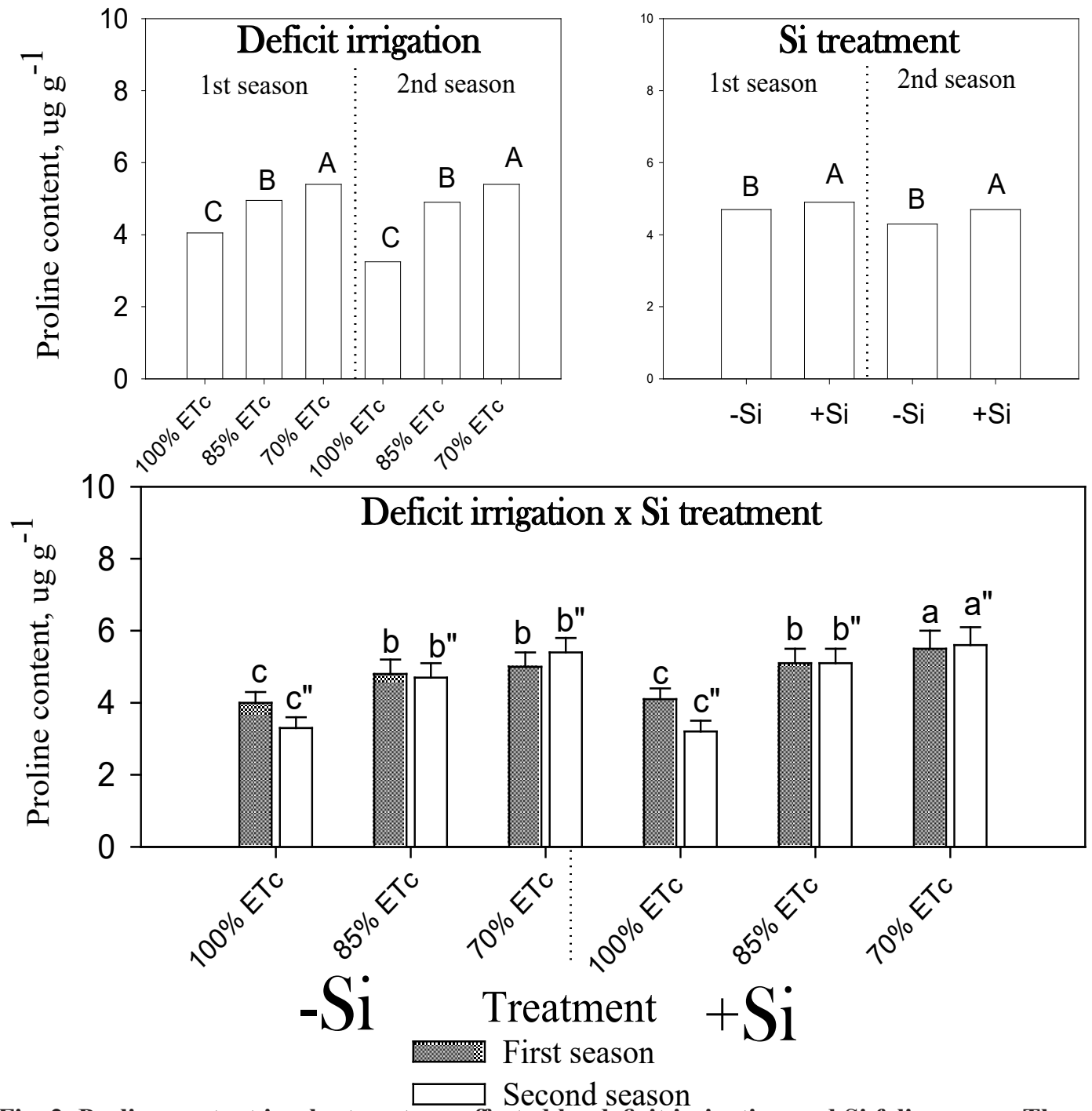

Fig. 2. Proline content in plant roots as affected by deficit irrigation and Si foliar spray. There were no significant variations among values of the same letter

TABLE 6. Proline content in plant roots as affected by deficit irrigation and Si foliar application

\begin{tabular}{|c|c|c|c|c|c|c|c|c|}
\hline \multirow{2}{*}{$\begin{array}{l}\mathrm{Si} \\
\text { spray }\end{array}$} & \multicolumn{5}{|c|}{ First season } & \multicolumn{3}{|c|}{ Second season } \\
\hline & $100 \% \mathrm{ET}_{\mathrm{c}}$ & $\mathrm{ET}_{\mathrm{c}} 85 \%$ & ET $_{c} 70 \%$ & Mean & $100 \% \mathrm{ET}_{\mathrm{c}}$ & $\begin{array}{l}85 \% \\
\text { ET }_{c}\end{array}$ & ET $_{c} 70 \%$ & Mean \\
\hline$-\mathbf{S i}$ & $4.0 \pm 0.3^{\mathrm{c}}$ & $4.8 \pm 0.4^{\mathrm{b}}$ & $5.0 \pm 0.4^{\mathrm{b}}$ & $4.7^{\mathrm{A}}$ & $3.3 \pm 0.3^{\mathrm{c}}$ & $4.7 \pm 0.4^{b}$ & $5.1 \pm 0.4^{\mathrm{b}}$ & $4.3^{\mathrm{B}}$ \\
\hline$+\mathbf{S i}$ & $4.1 \pm 0.3^{\mathrm{c}}$ & $5.1 \pm 0.4^{\mathrm{b}}$ & $5.5 \pm 0.5^{\mathrm{a}}$ & $4.9^{\mathrm{A}}$ & $3.2 \pm 0.3^{\mathrm{c}}$ & $5.1 \pm 0.4^{\mathrm{b}}$ & $5.6 \pm 0.5^{\mathrm{a}}$ & $4.7^{\mathrm{A}}$ \\
\hline Mean & $4.05^{\mathrm{C}}$ & $4.95^{\mathrm{B}}$ & $5.4^{\mathrm{A}}$ & - & $3.25^{\mathrm{C}}$ & $4.9^{\mathrm{B}}$ & $5.4^{\mathrm{A}}$ & - \\
\hline
\end{tabular}

There were no significant variations among values of the same letter, Si treatments:-Si: no Si spray; +Si: spray with 0.4 m $M$ K-silicate. 
TABLE 7. Chlorophyll A, B and total contents in tomato leaves grown under the conditions of deficit irrigation as affected by Si foliar application

\begin{tabular}{|c|c|c|c|c|c|c|c|c|}
\hline \multirow{2}{*}{$\begin{array}{l}\text { Si } \\
\text { spray }\end{array}$} & \multicolumn{4}{|c|}{ First season } & \multicolumn{4}{|c|}{ Second season } \\
\hline & $100 \% \mathrm{ET}_{\mathrm{c}}$ & $\begin{array}{c}85 \% \\
\text { ET }_{c}\end{array}$ & $\mathrm{ET}_{\mathrm{c}} \mathbf{7 0 \%}$ & Mean & $100 \% \mathrm{ET}_{\mathrm{c}}$ & $\begin{array}{c}85 \% \\
\text { ET }_{c}\end{array}$ & ET $_{c} 70 \%$ & Mean \\
\hline \multicolumn{9}{|c|}{ Chlorophyll A } \\
\hline$-\mathbf{S i}$ & $7.2 \pm 0.6^{\mathrm{ab}}$ & $6.5 \pm 0.5^{\mathrm{b}}$ & $2.5 \pm 0.2^{\mathrm{d}}$ & $5.4^{\mathrm{B}}$ & $7.0 \pm 0.6^{\mathrm{a}}$ & $6.3 \pm 0.5^{\mathrm{b}}$ & $2.9 \pm 0.3^{\mathrm{d}}$ & $5.4^{\mathrm{B}}$ \\
\hline$+\mathbf{S i}$ & $7.4 \pm 0.7^{\mathrm{a}}$ & $6.9 \pm 0.5^{\mathrm{ab}}$ & $3.6 \pm 0.4^{\mathrm{c}}$ & $6.0^{\mathrm{A}}$ & $7.1 \pm 0.7^{\mathrm{a}}$ & $6.8 \pm 0.7^{b}$ & $4.5 \pm 0.5^{\mathrm{c}}$ & $6.1^{\mathrm{A}}$ \\
\hline Mean & $7.3^{\mathrm{A}}$ & $6.7^{\mathrm{B}}$ & $3.1^{\mathrm{C}}$ & - & $7.03^{\mathrm{A}}$ & $6.55^{\mathrm{B}}$ & $3.7^{\mathrm{C}}$ & - \\
\hline \multicolumn{9}{|c|}{ Chlorophyll B } \\
\hline$-\mathbf{S i}$ & $4.6 \pm 0.5^{\mathrm{a}}$ & $4.1 \pm 0.3^{\mathrm{a}}$ & $2.3 \pm 0.2^{\mathrm{b}}$ & $3.7^{\mathrm{A}}$ & $4.8 \pm 0.4^{\mathrm{a}}$ & $3.9 \pm 0.4^{\mathrm{b}}$ & $2.1 \pm 0.2^{\mathrm{c}}$ & $3.6^{\mathrm{B}}$ \\
\hline$+\mathbf{S i}$ & $4.8 \pm 0.5^{\mathrm{a}}$ & $4.3 \pm 0.4^{\mathrm{a}}$ & $2.6 \pm 0.3^{\mathrm{b}}$ & $3.9^{\mathrm{A}}$ & $5.0 \pm 0.5^{\mathrm{a}}$ & $4.3 \pm 0.4^{b}$ & $2.7 \pm 0.3^{c}$ & $4.0^{\mathrm{A}}$ \\
\hline Mean & $4.7^{\mathrm{A}}$ & $4.2^{\mathrm{B}}$ & $2.5^{\mathrm{C}}$ & - & $4.9^{\mathrm{A}}$ & $4.8^{\mathrm{A}}$ & $2.4^{\mathrm{B}}$ & - \\
\hline \multicolumn{9}{|c|}{ Total chlorophyll } \\
\hline$-\mathbf{S i}$ & $11.8 \pm 0.9^{\mathrm{a}}$ & $10.6 \pm 0.9^{\mathrm{a}}$ & $4.8 \pm 0.5^{\mathrm{c}}$ & $9.1^{\mathrm{B}}$ & $11.8 \pm 1.0^{\mathrm{a}}$ & $10.2 \pm 0.9^{\mathrm{b}}$ & $6.2 \pm 0.5^{\mathrm{d}}$ & $9.4^{\mathrm{B}}$ \\
\hline$+\mathbf{S i}$ & $11.9 \pm 1.1^{\mathrm{a}}$ & $11.2 \pm 1.0^{\mathrm{a}}$ & $6.2 \pm 0.6^{\mathrm{b}}$ & $9.8^{\mathrm{A}}$ & $12.1 \pm 1.1^{\mathrm{a}}$ & $11.1 \pm 1.0^{\mathrm{ab}}$ & $7.2 \pm 0.6^{\mathrm{c}}$ & $10.1^{\mathrm{A}}$ \\
\hline Mean & $11.85^{\mathrm{A}}$ & $10.9^{\mathrm{B}}$ & $5.5^{\mathrm{C}}$ & - & $11.93^{\mathrm{A}}$ & $10.63^{\mathrm{B}}$ & $6.7^{\mathrm{C}}$ & - \\
\hline
\end{tabular}

There were no significant variations among values of the same letter, Si treatments:-Si: no Si spray; + Si: spray with $0.4 \mathrm{~m} M$ K-silicate.

Water use efficiency/water productivity

Tomato is a highly water consuming crop (Cantero-Navarro et al., 2016). Because of the water shortage, this crop may be cultivated under deficit irrigation ( $\mathrm{Lu}$ et al., 2019) and this may affect the outcome yield quantity and quality (Giuliani et al., 2018). Water use efficiency can be expressed in terms of amount of yield production $(\mathrm{kg})$ per unit consumption of irrigation water $\left(\mathrm{m}^{3}\right)$ (Jerry and Christian, 2019). Results indicate that deficit irrigation, increased water use efficiency (WUE). Decreasing the level of irrigation water from $100 \%$ to $85 \%$ ET recorded no significant variations in WUE during the first growing season; but, it increased WUE significantly in the second growing season (Fig. 3). Irrigation at $70 \% \mathrm{ET}_{\mathrm{c}}$ recorded further significant increases in WUE. These results agree with those obtained by Tahi et al. (2007) and Wang et al. (2018). Spraying plants with Si increased WUE significantly. It seems that Si regulates leaf transpiration and adjusts root hydraulic conductance (Chen et al., 2018). Also, $\mathrm{Si}$ may have decreased ROS accumulation in plants (Cao et al., 2019).

TABLE 7. Water use efficiency (WUE) in $\mathrm{kg} \mathrm{m}^{-3}$ for tomato plants grown under the conditions of deficit irrigation as affected by Si foliar application

\begin{tabular}{|c|c|c|c|c|c|c|c|c|}
\hline \multirow{2}{*}{$\begin{array}{l}\text { Si } \\
\text { spray }\end{array}$} & \multicolumn{4}{|c|}{ First season } & \multicolumn{4}{|c|}{ Second season } \\
\hline & $100 \% \mathrm{ET}_{\mathrm{c}}$ & $\mathrm{ET}_{\mathrm{c}} \mathbf{8 5 \%}$ & $70 \% \mathrm{ET}_{\mathrm{c}}$ & Mean & $100 \% \mathrm{ET}_{\mathrm{c}}$ & $\mathrm{ET}_{\mathrm{c}} 85 \%$ & $70 \% \mathrm{ET}_{\mathrm{c}}$ & Mean \\
\hline$-\mathbf{S i}$ & $12.91 \pm 0.92^{\mathrm{c}}$ & $12.90 \pm 1.09^{c}$ & $14.30 \pm 1.38^{\mathrm{b}}$ & $13.69^{\mathrm{B}}$ & $12.43 \pm 0.85^{\mathrm{c}}$ & $12.43 \pm 0.89^{\mathrm{c}}$ & $13.83 \pm 1.28^{\mathrm{b}}$ & $12.90^{\mathrm{B}}$ \\
\hline$+\mathbf{S i}$ & $12.98 \pm 1.02^{\mathrm{c}}$ & $14.36 \pm 0.98^{b}$ & $15.81 \pm 1.40^{\mathrm{a}}$ & $14.69^{\mathrm{A}}$ & $12.56 \pm 0.84^{\mathrm{c}}$ & $13.85 \pm 1.17^{\mathrm{b}}$ & $15.31 \pm 1,42^{\mathrm{a}}$ & $13.91^{\mathrm{A}}$ \\
\hline Mean & $12.94^{\mathrm{B}}$ & $13.63^{\mathrm{B}}$ & $15.06^{\mathrm{A}}$ & & $12.49^{\mathrm{C}}$ & $13.14^{\mathrm{B}}$ & $14.57^{\mathrm{A}}$ & \\
\hline
\end{tabular}

There were no significant variations among values of the same letter, Si treatments:-Si: no Si spray; +Si: spray with $0.4 \mathrm{~m} M \mathrm{~K}$-silicate. 

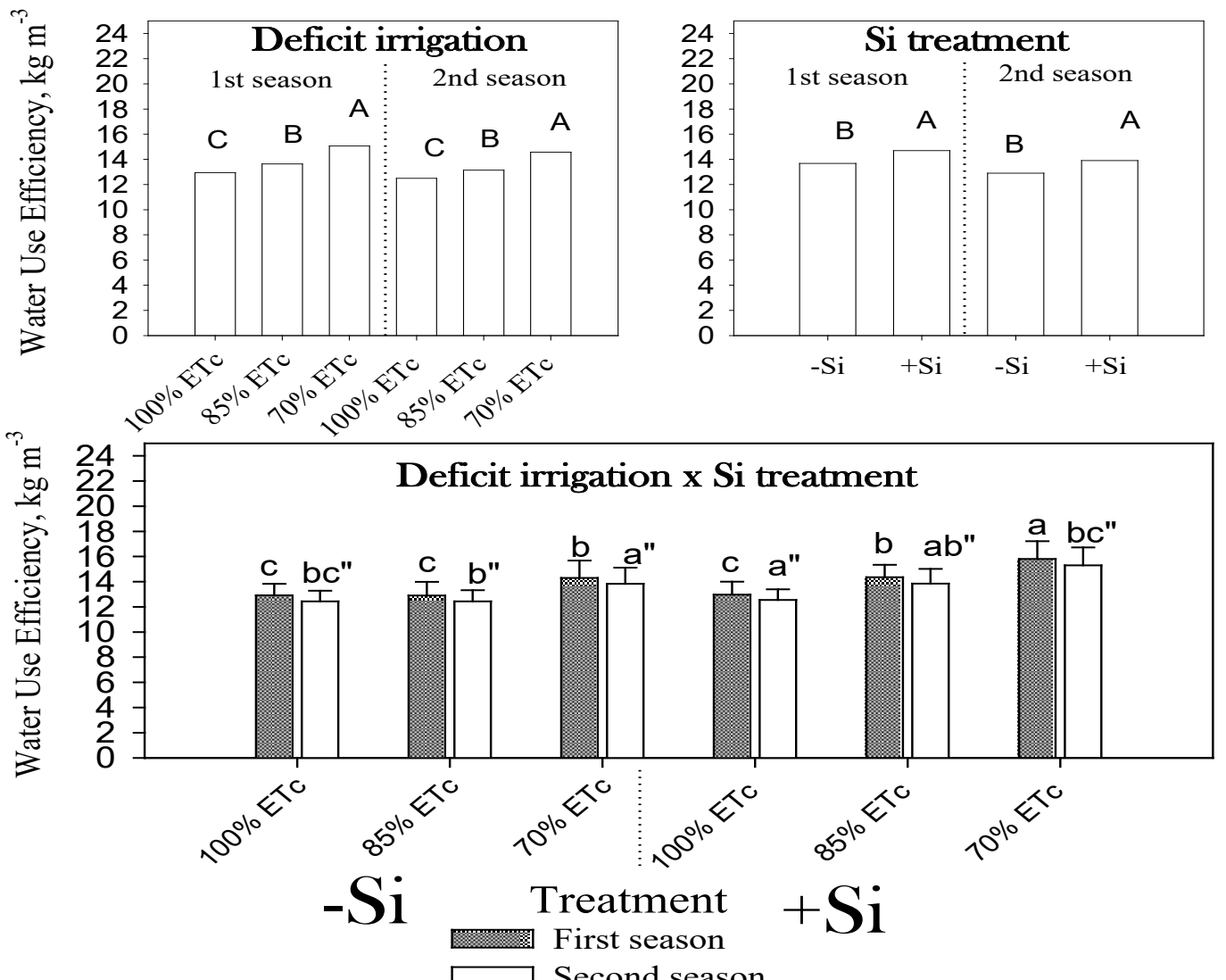

Fig 3. Water use efficiency (WUE) in $\mathrm{kg} \mathrm{m}^{-3}$ for tomato plants grown under the conditions of deficit irrigation as affected by $\mathrm{Si}$ foliar application. There were no significant variations among values of the same letter.

\section{Conclusion}

Spraying tomato plants (subjected to water stress conditions) with $\mathrm{Si}$ increased significantly chlorophyll A and B contents in leaves, as well as proline contents in roots. Such mechanisms might be responsible of the ameliorative effect of Si on tomato plants; hence increased its fruit yield. It is worthy to mention that the fruit yields attained for tomato plants subjected to irrigation with $85 \% \mathrm{ET}_{\mathrm{c}}$ and sprayed with $\mathrm{Si}$ were rather similar to those irrigated with $100 \% \mathrm{ET}_{\mathrm{c}}$. This; consequently, increased water use efficiency by tomato plants and; therefore, spraying tomato plants with Si can take part in saving considered amounts of water that can be used for irrigation of further areas for tomato.

\section{Acknowledgement}

The author would like to thank Prof Hassan H. Abbas, Prof. Aly A. Adel-Salam and Prof Mohamed H.H. Abbas (Soils and Water department, Faculty of Agriculture, Benha University, Egypt) for their support and assistance in writing the manuscript.

\section{References}

Abbas, M. and M. Bassouny (2018) Implications of long-term irrigation with wastewater on the contents and retention kinetics of potentially toxic elements in Typic Torripsamment soils. Egypt. J. Soil Sci., 58 (3), 337-357. doi: 10.21608/ ejss.2018.4232.1183

AbdAllah, S., El-Ramady, H., El-Sherbeni, A., Anber, H., Keshk, E., Hamed, S. and H. Amine (2019) Monitoring water quality of some canals in Delta Region, Egypt. Env. Biodiv. Soil Security, 3, 7395. doi: $10.21608 /$ jenvbs.2019.11428.1057

Abdelhafez, A.A., Metwalley,Sh.M. and H.H. Abbas (2020) Irrigation:Water Resources, Types and Common Problems in Egypt- Best Management Practices \& Evaluation. In: Technological and Modern Irrigation Environment in Egypt (E.-S. E. Omran and A. M. Negm, Ed.), Springer Water, Switzerland, pp. 15-34. doi:10.1007/978-3-03030375-4_2 
Al-aghabary, K., Zhu, Z. and Q. Shi(2005) Influence of silicon supply on chlorophyll content, chlorophyll fluorescence, and antioxidative enzyme activities in tomato plants under salt stress, J. Plant Nutr., 27 (12), 2101-2115, doi: 10.1081/PLN-200034641

Ali, M., Abdel-Hameed, A.H., Farid, I.M, Abbas, M.H.H. and H.H. Abbas (2016) To what extent can complimentary irrigation of wheat with wastewater, on soils along Belbais drain, affect soils? J. Soil Sci. and Agric Eng., Mansoura University. 7(6), 409416. doi:10.21608/jssae. 2016.39673

Ali, N., Schwarzenberg, A., Yvin, J.-C. and S.A. Hosseini (2018) Regulatory role of silicon in mediating differential stress tolerance responses in two contrasting tomato genotypes under osmotic stress. Front. Plant Sci., 9, 1475. doi:10.3389/ fpls.2018.01475

Allen, R.G., Pereira, L.S., Raes, D. and M. Smith (1998) Crop evapotranspiration — guidelines for computing crop water requirements. FAO Irrigation and drainage paper 56. Food and Agriculture Organization, Rome.

Amer, M. and F. El- Emary (2018) Impact of foliar with nano-silica in mitigation of salt stress on some soil properties, crop-water productivity and anatomical structure of maize and faba bean. Env. Biodiv. Soil Security, 2, 25-38. doi: 10.21608/ jenvbs.2018.3753.1026

AOAC (2000) Official Method of Analysis. AOAC International $17^{\text {th }}$ ed. Maryland, USA.

Assar, W., Ibrahim, M.G., Mahmod, W., Allam, A., Tawfik, A. and C. Yoshimura (2020) Effect of water shortage and pollution of irrigation water on water reuse for irrigation in the Nile Delta. J. Irrig. Drain E-ASCE, 146 (2), doi: 10.1061/(ASCE) IR.1943-4774.0001439

Ayyar, S. (2019) Mulching and fertigation on the yield and quality of tomato. Int. J. Chem. Stud. 7 (4), 2539-2541

Bassouny, M. and M. Abbas (2019) Role of biochar in managing the irrigation water requirements of maize plants: the pyramid model signifying the soil hydro-physical and environmental markers. Egypt. J. Soil Sci., 59 (2), 99-115. doi:10.21608/ ejss.2019.9990.1252

Bassouny, M. and M. Abbas (2020) Monitoring environmental pathways of trace elements in the northern east area of Egypt. Env. Biodiv. Soil Security. doi: 10.21608/jenvbs.2020.29403.1094
Bassouny, M., Abbas, M. and I. Mohamed (2020) Environmental risks associated with the leakage of untreated wastewater in industrial Areas. Egypt. J. Soil Sci., doi: 10.21608/ejss.2019.18787.1319

Bates, L.S.; Waidren, R.P. and I.D. Teare (1973) Rapid determination of free proline for water stress studies. Plant Soil, 39, 205-208.

Borghesi, E., Ferrante, A., Gordillo, B., RodríguezPulido, F.J., Cocetta, G., Trivellini, A., MensualiSodi, A., Malorgio, F. and F.J. Heredia (2016) Comparative physiology during ripening in tomato rich-anthocyanins fruits. Plant Growth Regul., 80, 207-214. doi:10.1007/s10725-016-0158-y

Booker, J.F. and W.S. Trees (2020) Implications of water scarcity for water productivity and farm labor. Water, 12, 308. doi:10.3390/w12010308

Cantero-Navarro, E., Romero-Aranda, R., FernándezMuñoz, R., Martínez-Andújar, C., Pérez-Alfocea, F. and A. Albacete (2016) Improving agronomic water use efficiency in tomato by rootstock-mediated hormonal regulation of leaf biomass, Plant Sci., 251, 90-100, doi:10.1016/j.plantsci.2016.03.001.

Cao, B., Ma, Q. and K. Xu (2019) Silicon restrains drought-induced ROS accumulation by promoting energy dissipation in leaves of tomato. Protoplasma. doi:10.1007/s00709-019-01449-0

Cao, B., Zhang, Z. and K. Xu (2017) Silicon improving water conservation, yield and quality of tomato under alternate wetting and drying condition. Transactions of the Chinese Society of Agricultural Engineering, 33 (22), 127-134(8)

Cao, B., Ma, Q., Zhao, Q., Wang, L. and K. Xu (2015) Effects of silicon on absorbed light allocation, antioxidant enzymes and ultrastructure of chloroplasts in tomato leaves under simulated drought stress, Sci. Hortic-Amsterdam, 194, 53-62, doi:10.1016/j.scienta.2015.07.037.

Chen, D., Wang, S., Yin, L. and X. Deng (2018) How does silicon mediate plant water uptake and loss under water deficiency?.Front plant sci., 9, 281. doi:10.3389/fpls.2018.00281

Dawa, K., Al-Gazar, T. and A. Abdel-Fatah (2019) Response of tomato plants to water irrigation levels and some foliar applications under drip irrigation system: 1- Vegetative growth and chemical constituents of L. J. Plant Production, 10 (3), 265273. doi: $10.21608 / j p p .2019 .36258$ 
De la Torre-González, Montesinos-pereira, D., Blasco, and J.M. Ruiz (2018) Influence of the proline metabolism and glycine betaine on tolerance to salt stress in tomato (Solanum lycopersicum L.) commercial genotypes, $J$. Plant Physiol., 231, 329-336, doi:10.1016/j. jplph.2018.10.013.

De Vos, R.C., Hall, R.D. and A. Moing (2018) Metabolomics of A Model Fruit: Tomato. In Annual Plant Reviews online, (J.A. Roberts, Ed.). doi:10.1002/9781119312994.apr0465

Dolatyar, M. and T.S. Gray (2000) Water Scarcity: A Global Problem?. In: Water Politics in the Middle East. Palgrave Macmillan, London, pp 60-84. doi: 10.1057/9780230599871_3

Domokos-Szabolcsy, E., Alshaal, T., Elhawat, N., Abdalla, N., Reis, A. and H. El-Ramady (2017) The interactions between selenium, nutrients and heavy metals in higher plants under abiotic stresses. Env. Biodiv. Soil Security, 1, 5-31. doi: $\underline{10.21608 / j e n v b s .2017 .951 .1001}$

Durand, M., Brendel, O., Buré, C., Courtois, P., Lily, J.-B., Granier, A. and D. Le Thiec, (2020) Impacts of a partial rainfall exclusion in the field on growth and transpiration: consequences for leaf-level and whole-plant water-use efficiency compared to controlled conditions, Agr. Forest Meteorol., 282-283,107873, doi:10.1016/j. agrformet.2019.107873.

Elshony, M., Farid, I., Alkamar, F., Abbas, M. and H. Abbas (2019) Ameliorating a sandy soil using biochar and compost amendments and their implications as slow release fertilizers on plant growth. Egypt. J. Soil Sci., 59 (4), 305-322. doi: 10.21608/ejss.2019.12914.1276

Farid, I., Abbas, M., Bassouny, M., Gameel, A. and H. Abbas (2019) Indirect impacts of irrigation with low quality water on the environmental safety. Egypt. J. Soil Sci. 60 (1), 1-15. doi: 10.21608/ejss.2019.15434.1294

Farid, I., Abbas, M. and E. Fawzy (2014) Rationalizing the Use of Water of Salinity Hazards for Irrigating Maize Grown in a Saline Sodic Soil. Egypt. J. Soil Sci., 54 (2), 163-175. doi: 10.21608/ejss.2014.131

Farid, I., Hashem, A., Abd El-Aty, E., Abbas, M. and M. Ali (2020) Integrated approaches towards ameliorating a saline sodic soil and increasing the dry weight of barley plants grown thereon. Env. Biodiv. Soil Security, 4, 31-46. doi: 10.21608/ jenvbs.2020.12912.1086
Giuliani, M.M., Carucci, F., Nardella, E., Francavilla, M., Ricciardi, L., Lotti, C. and G. Gatta (2018) Combined effects of deficit irrigation and strobilurin application on gas exchange, yield and water use efficiency in tomato (Solanum lycopersicum L.), Sci., Hortic-Amsterdam, 233,149-158, doi:10.1016/j.scienta.2018.01.052.

Gladden, L., Wang, Y.-M., Hsieh, C.-H. and I. Tsou, (2012) Using deficit irrigation approach for evaluating the effects of water restriction on field grown tomato (Lycopersicon esculentum). Afr. J. Agric. Res., 7, 2083-2095. doi:10.5897/ AJAR11.876.

Gomez, K.A. and A.A. Gomez (1984) Statistical Procedures in Agricultural Research. John Wiley and Sons, New York, $2^{\text {nd }}$ ed.

Grašič, M., Dobravc, M., Golob, A., Vogel-Mikuš, K. and A. Gaberščik, (2019) Water shortage reduces silicon uptake in barley leaves, Agric. Water Manage., 217, 47-56, doi:10.1016/j.agwat.2019.02.030

Guichard, S., Gary, C., Leonardi, C. and N. Bertin (2005) Analysis of growth and water relations of tomato fruits in relation to air vapor pressure deficit and plant fruit load. J. Plant Growth Regul., 24, 201. doi:10.1007/s00344-005-0040-Z

Hanssens, J., De Swaef, T. and K. Steppe (2015) Light changes xylem contribution to fruit. Plant Cell Environ., 38, 487-498. doi:10.1111/ pce. 12411

Ibrahim, Z.K., Abdel-Hameed, A.H., Farid, I.M., Abbas, M.H.H. and H.H. Abbas (2016) Implications of using Belbais drain water for irrigation of wheat in the North East region of Egypt. J. Soil Sci. and Agric Eng., Mansoura University., 7 (3), 1-12. doi: 10.21608/jssae.2016.39394

Jarosz, Z. (2014) The effect of silicon application and type of medium on yielding and chemical composition of tomato. Acta Sci. Pol., Hortorum Cultus., 13 (4) 2014, 171-183

Jerry L. H. and D. Christian (2019) Wateruse efficiency: Advances and challenges in a changing climate. Front Plant Sci. 10, 103. doi:10.3389/fpls.2019.00103

Jurkowska, A. and E. Świerczewska-Gładysz (2020) New model of Si balance in the Late Cretaceous epicontinental European Basin, Global Planet Change, 186, 103108. doi:10.1016/j. gloplacha.2019.103108.

Kaushik, P. and D.K. Saini (2019) Silicon as a vegetable crops modulator-A review. Plants, 8, 148. doi:10.3390/plants 8060148 
Liu, J., Hu, T., Feng, P., Wang, L. and S. Yang (2019) Tomato yield and water use efficiency change with various soil moisture and potassium levels during different growth stages. PLoS ONE 14 (3), e0213643. doi:10.1371/journal. pone. 0213643

Lu, J., Shao,G., Cui, J., Wang, X. and L. Keabetswe (2019) Yield, fruit quality and water use efficiency of tomato for processing under regulated deficit irrigation: A meta-analysis, Agric. Water Manage., 222, 301-312, doi:10.1016/j.agwat.2019.06.008.

Marodin, J. C., Resende, J. T.V., Morales, R. G.F., Silva, M. L.S., Galvão, A. G. and D. S. Zanin (2014). Yield of tomato fruits in relation to silicon sources and rates. Hortic. Bras., 32 (2), 220224. doi:10.1590/S0102-05362014000200018

Mbava, N., Mutema, M., Zengeni, R., Shimelis, H. and V. Chaplot (2020) Factors affecting crop water use efficiency: A worldwide meta-analysis, Agric Water Manage., 228,105878, doi:10.1016/j. agwat.2019.105878.

Nahar, K. and S. M. Ullah (2018) Drought stress effects on plant water relations, growth, fruit quality and osmotic adjustment of tomato (Solanum lycopersicum) under subtropical condition. Asian J. Agro. Horti. onfarm Res., 1 (2), 1-14. doi:10.9734/ AJAHR/2018/39824

Page, A.L., Miller, R.H.and D.R. Keeney (1982) Methods of Soil Analysis, Part 2. Soil Soc. Amer. Inc., Madison, Wisconsin, USA

Rafaat, R., Osman, H., Georgy, M. andM. Elsaid (2020) Preferred risk allocation in Egypt's water sector PPPs, Int. J. Constr. Manag., doi: 10.1080/15623599.2019.1703087

Richards, L.A. (1954) Diagnosis and Improvement of Saline and Alkali Soils, Agriculture Handbook 60, US Department of Agriculture, Washington, DC.

Ripoll, J., Brunel, B., L¿Hôtel, J.-C., Garcia, G., Bertin, N. and L. Urban (2016) Impact of water deficit on tomato fruit growth and quality depending on the fruit developmental stage. Acta Hortic., 1112, 173178 doi: 10.17660/ActaHortic.2016.1112.24

Saad, M. andH. Abo-Koura (2018) Improvement of sorghum (Sorghum bicolor 1. Moench) growth and yield under drought stress by inoculation with Bacillus cereus and foliar application of potassium silicate. Env. Biodiv. Soil Security, 2, 205-221. doi: 10.21608/jenvbs.2019.6790.1045

Sithanantham, S., Prabakaran, M. andP. Narayanasamy (2020) Potential of Silica Sources Including Fly Ash as Green Technology Inputs to Induce Resistance to Biotic and Abiotic Stresses in Crop Plants: Overview. In: Ghosh S., Kumar V. (Ed.) Circular Economy and Fly Ash Management. Springer, Singapore, pp: 135-144. doi: 10.1007/978-981-150014-5_10

Shi, Y., Zhang, Y., Yao, H., Wu, J., Sun, H. andH. Gong (2014) Silicon improves seed germination and alleviates oxidative stress of bud seedlings in tomato under water deficit stress, Plant Physiol. Biochem., 78, 27-36, doi: 10.1016/j.plaphy.2014.02.009.

Subramani, T. and D.J. Prabakaran (2015) Uniformity studies and performance of sprinkler and drip irrigation. Int. J. Appl. Innov. Eng. Manag., 4 (5), 284-293

Sun, H, Duan, Y, Mitan-Ueno, N, Che, J., Jia, J., Liu, J., Gou, J., Ma, J.F. andH. Gong (2019) Tomato roots have a functional silicon influx transporter but not a functional silicon efflux transporter. Plant Cell Environ., 1-13. doi: 10.1111/pce.13679

Tahi, H., Wahbi, S., EL Modafar, C., Aganchich, A. andR.Serraj (2008) Changes in antioxidant activities and phenol content in tomato plants subjected to partial root drying and regulated deficit irrigation, Plant Biosyst., 142 (3), 550-562, doi: 10.1080/11263500802410900

Tahi, H., Wahbi, S., Wakrim, R., Aganchich, B., Serraj, R. andM. Centritto, (2007) Water relations, photosynthesis, growth and water-use efficiency in tomato plants subjected to partial rootzone drying and regulated deficit irrigation, Plant Biosyst., 141 (2), 265-274, doi: 10.1080/11263500701401927

Teixeira, G.C.M., de Mello Prado, R., Rocha, A.M.S. dos Santos, L.C.N., Sarah, M.M.d.S., Gratão, P.L. and C. Fernandes (2020) Silicon in pre-sprouted sugarcane seedlings mitigates the effects of water deficit after transplanting. J. Soil Sci. Plant Nutr. doi: 10.1007/s42729-019-00170-4

Tóth, A. R. andM. Takácsné Hájos (2019) Rheological evaluation of industrial tomato. Acta Agraria Debreceniensis, 2, 137-140. doi:10.34101/ actaagrar/2/3692

Wang, C., Wu, S., Tankari, M., Zhang, X., Li, Li, Gong, D., Hao, W., Zhang, Y., Mei, X., Wang, Y., Liu, F. andY. Wang (2018)Stomatal aperture rather than nitrogen nutrition determined water use efficiency of tomato plants under nitrogen fertigation, Agric Water Manage., 209, 94-101, doi:10.1016/j. agwat.2018.07.020.

Zargar, S.M., Mahajan, R., Bhat, J.A., Nazir, M. andR. Deshmukh (2019) Role of silicon in plant stress 
tolerance: opportunities to achieve a sustainable cropping system. 3 Biotech 9, 73. doi:10.1007/ s13205-019-1613-Z

Zekri S. and A. Al-Maamari (2020) An Overview of the Water Sector in MENA Region. In: Zekri S. (Ed.) Water Policies in MENA Countries. Global Issues in Water Policy, 23,1-17. doi:10.1007/978-3-03029274-4_1

Zhu, Y. and H. Gong (2014) Beneficial effects of silicon on salt and drought tolerance in plants. Agronomy for Sustainable Development, 34 (2), pp.455- 472. doi:10.1007/s13593-013-0194-1. Zhu, Y. and H. Gong (2014) Beneficial effects of silicon on salt and drought tolerance in plants. Agronomy for Sustainable Development, 34 (2), pp.455472. doi:10.1007/s13593-013-0194-1. 